\title{
PERAN PEMUDA MEMBANGUN DESA: PENGABDIAN TERHADAP REMAJA ISLAM WATUALANG
}

\author{
Hanifah Hikmawati, S.S., M.Sos \\ Institut Agama Islam Ngawi \\ hanifah_hikmawati@yahoo.com
}

\begin{abstract}
Abstrak: Artikel ini membahas hasil pengabdian terhadap remaja desa Watualang yang bergerak pada bidang keagamaan sebagai upaya menangkal radikalisme dan meningkatkan kualitas diri melalui pendidikan. Remaja Islam Watualang (Riswa) yang terbentuk pada 16 September 2016 merupakan organisasi kepemudaan desa yang terus melakukan inovasi dan kreativitas dalam menjunjung nilai-nilai perdamaian, persaudaraan, dan persatuan. Adanya kelompok remaja ini sekaligus sebagai mediator perkumpulan remaja kekinian yang memberi warna baru tentang corak dakwah yang nyaman. Untuk mengetahui sebab apa saja yang menjadikan kelompok ini lahir, maka dirumuskan beberapa rumusan masalah dalam memudahkan pembahasan dan analisis dalam artikel ini. Pertama, bagaimanakah fenomena radikalisme dan terorisme mengancam generasi muda di Indonesia?. Kedua, bagaimanakah eksistensi Remaja Islam Watualang dalam melakukan dakwah untuk membentengi diri dari bahaya radikalisme dan terorisme. Metode yang digunakan adalah deskriptif kualitatif dengan menyajikan sumber data dari jurnal dan hasil penelitian terdahulu, serta beberapa dokumentasi hasil pengabdian terhadap Riswa. Hasil yang diperoleh pada pengabdian ini adalah Riswa aktif melaksanakan rutinitas pembacaan maulidur-rasul dalam acara Malam Tadarus Puisi (Matapu), smeinar-seminar, outbond edukasi, dan beberapa bentuk dakwah yang lainnya.
\end{abstract}

Kata kunci: Radikalisasi dan terorisme, pengabdian, remaja Islam Watualang (Riswa)

\section{Pemberdayaan Sumber Daya Manusia}

Desa adalah akar masyarakat yang mempunyai banyak potensi dalam perkembangan nasional. Di dalamnya terdapat penduduk yang berprofesi sesuai bidangnya, seperti halnya pertanian, peternakan, dan sebagainya untuk bertahan hidup dalam memperoleh ekonomi dan pangan. Penduduk ini yang menjadi sumber daya manusia yang wajib dipertahankan sebagai pemeran keberlangsungan kehidupan. Sebagaimana yang dikatakan Sumodiningrat (2016:xv), potensi dan daya yang dimiliki masyarakat (empowering) harus diperkuat. Diperlukan berbagai ide dan gagasan kreatif serta langkah-langkah positif untuk menciptakan iklim dan suasana. Penguatan ini meliputi langkah-langkah nyata, dan menyangkut penyediaan berbagai masukan (input), pembukaan akses dalam berbagai peluang (opportunities) yang akan mendorong 
masyarakat menjadi berdaya.

Termasuk di dalamnya adalah peluang dalam mencerdaskan sumber daya manusia, khususnya adalah kaum pemuda/remaja. Upaya pencerdasan ini dimulai dengan memperkuat aspek spiritualisme keagamaan sebagai bekal keimanan dan ketakwaan. Hal ini sebagai benteng pencegahan dari kenakalan remaja, juga sebagai benteng pertahanan diri dari serangan radikalisme yang dapat mengakibatkan pertumpahan darah. Maka, membangun pemberdayaan bagi masyarakat desa adalah penting dilakukan untuk mencegah hal-hal diskriminasi dan ketimpangan serta keburukan yang terjadi.

\section{Keresahan Remaja Di Era Zaman Now}

Belakangan ini, masyarakat disibukkan oleh penggiringan media yang senter dengan sikap intoleransi terhadap perbedaan suku, ras, dan agama. Berbagai kepentingan diusahakan terwujud, sekalipun cara perwujudan itu dengan menebar kebencian dan berita-berita bohong atau yang kini dikenal dengan hoax. Tidak terkecuali perihal toleransi dalam konsep bernegara yang sejatinya bukan lagi menjadi sesuatu yang usang dan a priori. Landasan bernegara yang sudah termaktub dalam UUD 1945 dan pancasila adalah dua bukti sentral ijtihad para pahlawan dan ulama' yang menjunjung tinggi persatuan berbangsa dan bernegara dalam kesatuan NKRI.

Intoleransi tersebut lalu menyebabkan radikalisme dan terorisme berkembang biak di beberapa negara termasuk Indonesia. Isu radikalisme dan terorisme yang dulu dianggap sebagai skenario Barat untuk memecah belah umat dan membuat stigma buruk terhadap Islam, kini sudah tidak lagi dipercaya. Banyak bukti yang menyatakan bahwa radikaslime dan terorisme benar adanya dan beberapa kali terjadi menimpa negara dan mengakibatkan dampak keresahan yang berkepanjangan. Hal ini ditandai dengan adanya teror yang terjadi di Indonesia terus beruntun (Fanani, 2013:4). Dari kejadian itu kita menyaksikan fakta berupa testimoni dan jaringan yang dibentuk mereka. Fakta itu mengatakan bahwa memang ada orang-orang yang mendedikasikan dirinya sebagai teroris, menebar ilmu teror, dan meyakinkan orang-orang untuk mengikuti pemahaman Islam ala teroris.

Fenomena ini muncul dengan ditandai jatuhnya rezim orde baru. Kelompok keagamaan yang pada mulanya bergerak di bawah tanah (underground), atau setidaknya berkembang di kalangan terbatas, pada saat kejatuhan rezim Orde Baru muncul secara lebih terbuka untuk 
memperkuat basis massa dan memperluas jaringannya. Jaringan tersebut tentu berbeda dengan pemahaman keagamaan yang telah lebih dulu berkembang pesat di era sebelumnya. Fenomena ini rupanya dilatari oleh munculnya kelompok keagamaan di kalangan Islam yang mengusung paham, ideologi, dan gerakan yang tidak saja berbeda, bahkan bertentangan dengan kelompok keagamaan arus utama (mainstream), seperti Muhammadiyah dan Nahdlatul Ulama (NU). Kedua organisasi keagamaan terbesar yang berdiri pada 1912 dan 1926 ini dikenal memiliki paham yang moderat (Arifin, 2014:393). Maka, pemahaman isu terorisme yang diciptakan Barat adalah isu yang tidak terbukti kebenarannya. Karena, terorisme menjadi fakta nyata yang mereka yakini, dan jalani. Keyakinan itu diperkuat dengan pemahaman kebenaran tunggal mereka dan meyakini selain golongan mereka adalah salah dan kafir. Tidak sedikit menggunakan kekerasan dan pemaksaan untuk membujuk orang lain masuk ke dalam kelompok mereka. Termasuk sasarannya adalah kelompok pemuda/remaja.

Sebagaimana yang dikutip dari situs media www.nu.or.id, berdasarkan hasil survei yang dilakukan oleh PPIM UIN Syarif Hidayatullah pada akhir 2017 menunjukkkan adanya potensi radikalisme di kalangan generasi Z, yaitu generasi yang lahir sejak pertengahan 1990-an sampai pertengahan 2000an. Temuannya adalah sebesar 37.71 persen memandang bahwa jihad atau khital, alias perang, terutama perang melawan non-Muslim. Selanjutnya 23.35 persen setuju bahwa bom bunuh diri itu jihad Islam. Lalu 34.03 persen setuju kalau Muslim yang murtad harus dibunuh. Temuan lain, 33,34 persen berpendapat perbuatan intoleran terhadap kelompok minoritas tidak masalah. Para generasi Z ini mereka mendapatkan banyak materi Islam salah satunya dari internet dan medsos.

Hal ini semakin diperkuat dengan sejarah awal tahun 1990-an (Qodir, 2007:44), pada saat itu, agama-agama tidak lagi menjadi bagian pembebasan umat, namun justru menjadi penabur benih-benih pertentangan di antara penganut agama yang berbeda-beda. Lalu muncullah berbagai aktivitas dialog antariman, yang dianggap sebagai cikal bakal gerakan interfaith, di mana banyak orang berbeda agama formal mampu duduk bersama, membahas persoalan teologi, doktrin agama, praksis agama dengan segala keterbukaan, kejujuran, kesetaraan, tanpa disertai ingin menang sendiri dengan tujuan menjatuhkan agama lain, mencela dan menjelekkan agama lain, bahkan mengkafirkan.

Vol. 1 No. 1, April 2019 
Kafir-mengkafirkan menjadi jargon paling senter bagi aktivis dialog antariman dalam melemahkan persaudaraan antar agama. Jargon tersebut, secara terang-terangan menjadi bukti sikap intoleransi yang dapat mengakibatkan menurunnya semangat nasionalisme yang dijalani kaum muda. Tidak hanya itu, diskreditas terhadap melemahnya rasa cinta tanah air yang kian mencolok itu seolah menjadi jebakan bagi kaum muda, di antaranya stagnasi minimnya pergerakan dan perubahan yang dilakukan dalam progresifitas kemajuan bernegara. Hal ini dikarenakan banyak pemuda hanya sibuk mencibir pemeluk agama, berita-berita hoax yang belum tentu benar, dan menjadikan mereka melupakan kewajiban lain dalam menerapkan peran sosial.

Spirit bangsa sejatinya telah memberi pelajaran bagi kita; siapapun wajib mengimplemenatasikan sikap toleransi sebagai sikap kemanusiaan yang terus diulas demi menjunjung tinggi kerukunan, kesejahteraan, dan kemakmuran bangsa, lalu didukung dengan upaya progresifitas pendidikan dalam menunjang cita-cita kemandirian tanah air Indonesia sebagai upaya penanggulangan terhadap angka pendidikan rendah, kemiskinan, pengangguran, dan kesenjangan sosial yang terjadi.

Atas keresahan dan problematik yang terjadi itu, muncullah ide dan gagasan untuk membentuk sebuah kelompok remaja untuk menaungi dan memberi edukasi keagamaan dan kebangsaan sebagai benteng pertahanan dari ancaman radikalisme dan terorisme. Remaja Islam Watualang (Riswa) menjadi wadah perkumpulan remaja sebagai solusi alternatif sekaligus upaya aktualisasi nilai-nilai kebangsaan dan nasionalisme dalam menjaga keutuhan NKRI. Hal ini dikarenakan pemuda Islam merupakan identitas yang dibekali keilmuan agama dari bidang sejarah, falsafah, fiqih, tarikh, dan sebagainya yang mempunyai tugas besar melanjutkan estafet perjuangan menjaga eksistensi peradaban Islam di nusantara. Riswa bergerak dalam bidang edukasi pendidikan yang kekinian untuk menunjang kebutuhan mereka.

\section{Deklarasi Remaja Islam Watualang}

Watualang adalah salah satu desa yang terletak di kawasan pusat kota Ngawi, tepatnya di Jalan Raya Solo-Ngawi kilometer 4. Berdekatan dengan terminal Kertonegoro Ngawi, Watualang menjadi desa yang masih kental dengan sistem cocok tanam pertanian. Warga di dalamnya termasuk warga yang gigih, bekerja keras, dan berjiwa besar. 


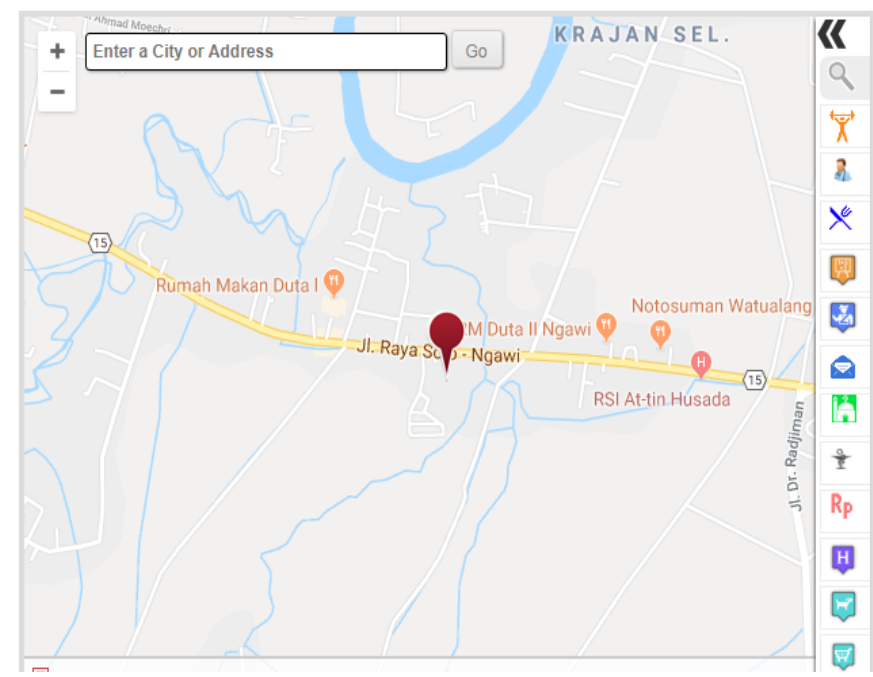

Gambar 1 : Peta desa Watualang (sumber: google.com)

Menjadi desa yang terletak di pusat kota tentu sering mendapat berbagai pertukaran informasi dan transaksi komunikasi yang pesat. Dialog yang terjadi antar warga menjadi media transformasi berbagai bentuk keragaman isu-isu keagamaan dan kenegaraan. Maka tidak sedikit muncul gerakan-gerakan keagamaan yang berambisi mendirikan negara Islam di tanah Nusantara yang notabene terdapat beribu suku dan kebudayaan ini. Di samping itu, informasi kriminalitas juga semakin muncul silih berganti. Kasus pencurian, pemerkosaan, perkelahian, kerap dilakukan pemuda di era zaman now ini. Hal ini menguatkan ciri degradasi moral yang harus secepat mungkin diatasi. Maka, muncullah Riswa sebagai ajang media edukasi pendidikan non-formal dalam menunjang kebutuhan remaja untuk menangkal gerakan radikalisme dan kenakalan remaja. Berbagai bentuk pendidikan diaplikasikan dalam dakwah, seni, dan budaya. Munculnya Riswa yang dibentuk pada 18 September 2016 sekaligus sebagai pemertahanan tradisi. Kreativitas praktik dakwah melibatkan interaksi tradisi, budaya dan agama. Masyarakat yang mempertahankan tradisi agama sebagai bagian dari kehidupannya, secara tidak langsung akan membentuk sebuah masyarakat religius, dan muncul kesadaran mengamalkannya (Hikmawati, 2018:87).

Deklarasi Remaja Islam Watualang (RISWA) terbentuk pada 18 September 2016, mengusung visi misi sebagai berikut.

Vol. 1 No. 1, April 2019 


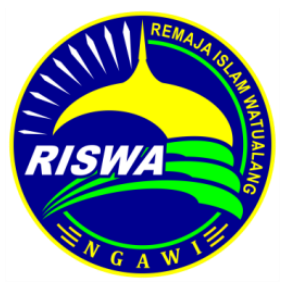

\section{Visi :}

"Menuju generasi yang santun, bijak, madani, dan rabbani".

\section{Misi :}

1. Mempererat silaturrahmi remaja desa Watualang

2. Terbuka untuk semua remaja desa watualang

3. Didirikan sebagai wadah syi'ar islam desa watualang

4. Bersahabat dan menerima setiap kreativitas islamiyah yang dimiliki setiap dusun di desa Watualang

\section{LAMBANG :}

1. Warna dasar biru, berlingkar kuning di tepinya dengan diapit.

2. Terdapat 3 sabit berukuran berbeda warna hijau, lebih besar yang bawah kemudian semakin keatas semakin kecil. Kemudian diatasnya sebagai ujung terdapat kubah masjid berada di tengah warna kuning.

3. Di tengahnya terdapat akronim "RISWA" warna putih.

4. 9 garis sinar dari bawah ke atas semakin panjang warna putih.

5. Redaksi "REMAJA ISLAM WATUALANG" berada di pojok kanan atas mengikuti pola lingkaran warna kuning.

6. Terdapat akronim "NGAWI" yang diapit 3 garis yang berbeda, berada di samping kanan kiri warna kuning.

7. Terdapat lingkanran tidak utuh warna hijau sebagai pembatas tulidan Ngawi dan Remaja Islam Watualang.

\section{ARTI LAMBANG :}

\section{Warna}

1. Biru; kestabilan continue, mental percaya diri;

2. Kuning; keceriaan, kejayaan, dan optimis; 
3. Hijau; konsep madani yang dibangun dengan kesejukan, kesuburan dan pembaharuan dalam berinovasi; dan

4. Putih; suci, bersih, dan kebebasan dalam kebijaksanaan.

\section{Bentuk Lambang}

1. Lingkaran; continue, tidak ada ujungnya, stabil dalam pergerakan keremajaan.

\section{Pewarnaan;}

a. Lingkaran biru; percaya diri, belajar, perjuangan, dan pengabdian yang tidak pernah berakhir.

b. Lingkaran kuning bagian luar; dijaga karakter optimisme yang selalu membawa kejayaan.

2. Kubah masjid; masjid menjadi centre pergerakan keislaman oleh remaja islam.

\section{Pewarnaan;}

a. Kubah kuning; kejayaan berada di atas, menuju kesempurnaan yang Hakiki, menuju keberadaan di atas dari segala atas.

3. 3 sabit di bawah kubah; pondasi yang kuat dalam pergerakan keremajaan (Islam, Iman, Ihsan)/insan kamil. Ukuran sabit menuju keatas yang semakin kecil, menunjukkan bahwa persatuan dari jamaah yang menjadi satu, menuju pengabdian hanya kepada Tuhan yang maha Esa.

\section{Pewarnaan;}

a. Pondasi sabit warna hijau; kesuburan pondasi sebagai sumber inovasi yang tidak pernah kehabis referensi, tersimpan dalam kekayaan tanah.

4. 9 sinar cahaya; kebermanfaatan Riswa terhadap umat manusia, pada umat islam watualang khususnya.

\section{Pewarnaan;}

a. Sinar putih; kesucian pembelajaran dan perjuangan, serta kebijaksanaan dalam bersikap.

5. Jumlah 9; menunjukkan bahwa konsep perjuangan walisongo, penebar syariat islam rabmatan lil 'Alamiin. atau gabungan dari yang 9 unsur tauladan, dari yang paling besar

(Nabi Muhammad Saw, Abu Bakar, Umar bin Khottob, Usman bi Affan, Ali bin Abi 
Tholib, Imam Maliki, Imam Hanafi, Imam Syafi'i, Imam Hambali). Sinar 9 bersudut 4; persaudaran(sekawan/dalam bahasa jawa) 4 lelaku manusia. 4 adalah sifat Bumi (Perspektif Kejawen).

Selain visi misi, Riswa juga telah terbentuk struktur kepengurusan yang mencakup seluruh masyarakat, khususnya kaum remaja Islam Watualang dari berbagai dusun yang ada di dalamnya. Kepala desa Watualang menjadi pelindung Riswa dalam kepengurusannya, dan keberadaan Riswa ini telah membentuk sub-organisasi keremajaan yang dinaungi langsung di bawah Pemerintah Desa Watualang.

\section{Merawat Kebangsaan Dan Nasionalisme}

Realisasi gerakan pendidikan dalam menyongsong nilai-nilai nasionalisme dapat dimulai dengan mengumpulkan para pemuda maupun remaja dalam satu wadah. Perkumpulan ini dilakukan sebagai optimalisasi penerapan paradigma berpikir kritis terhadap esensi Islam rahmatan lil'alamin, yaitu islam yang menebar kasih sayang, toleransi, dan moderat. Esensi islam di Nusantara yang sudah dikenalkan Walisongo berupa sikap ramah dan menjaga perdamaian patut dan perlu untuk dipertahankan untuk menangkal radikalisme (Winarni, 2016:74).

Hal ini sesuai dengan historisitas corak Islam khas Nusantara (Baso, 2015:9) yang memaparkan bahwa meskipun NKRI tidak ditemukan dalilnya dalam Al-Qur'an dan Al-Hadis, tapi terdapat dalil ijma' ulama Islam Nusantara, yang menetapkan bahwa negara kita sebagai darul-Islam, seperti konteks negara Hindia Belanda masa itu yang esensinya tidak mengikuti hukum-hukum darul Islam seperti dikenal dalam fiqih. Namun lebih kepada esensi maqashid syariat atau kemaslahatan. Para ulama' sepakat dalam hal ini menafsirkan hakikat bentuk kenegaraan kita bukan sebagai negara Islam (daulah Islamiyah), nmaun sebagai negara yang menjamin keselamatan (darus salam).

Maka penting bagi kita aktif mempertahankan esensi Islam yang demikian ini agar generasi bangsa tidak memungkiri sejarah dan perjuangan para pahlawan dalam merebut kemerdekaan. Apalagi ancaman radikalisme dan terorisme kian meresahkan keberagaman Nusantara. Perlu tindakan nyata bagi pemuda untuk menyalurkan warisan pengetahuannya kepada masyarakat. Di antaranya adalah membuat perkumpulan remaja, membentuk halaqoh, 
majelis, yang di dalamnya diisi dengan penguatan akidah Islam Ablussunnah Waljamaah.

Spirit demikian ini menjadi modal awal dalam mengoptimalkan masa muda sebagai waktu dan momen yang tidak akan datang dua kali. Borgias (2013:53) mengatakan bahwa waktu selalu mengarah pada masa depan yang menjadi benang merah penghubung masa lalu yang kemudian membentuk tanda dinamika kehidupan manusia yang menyejarah.

\section{Progresifitas Remaja Islam Watualang}

Sejak dideklarasikan sebagai media perkumpulan remaja, Riswa mengkonsep acara rutinan mingguan dan bulanan. Acara tersebut dilakukan sebagai pemenuhan mediasi pendidikan yang diharapkan menjadi bekal remaja. Bekal ini sebagai pedoman untuk menekan angka kenakalan remaja dan geliatnya isu radikalisme yang terjadi.

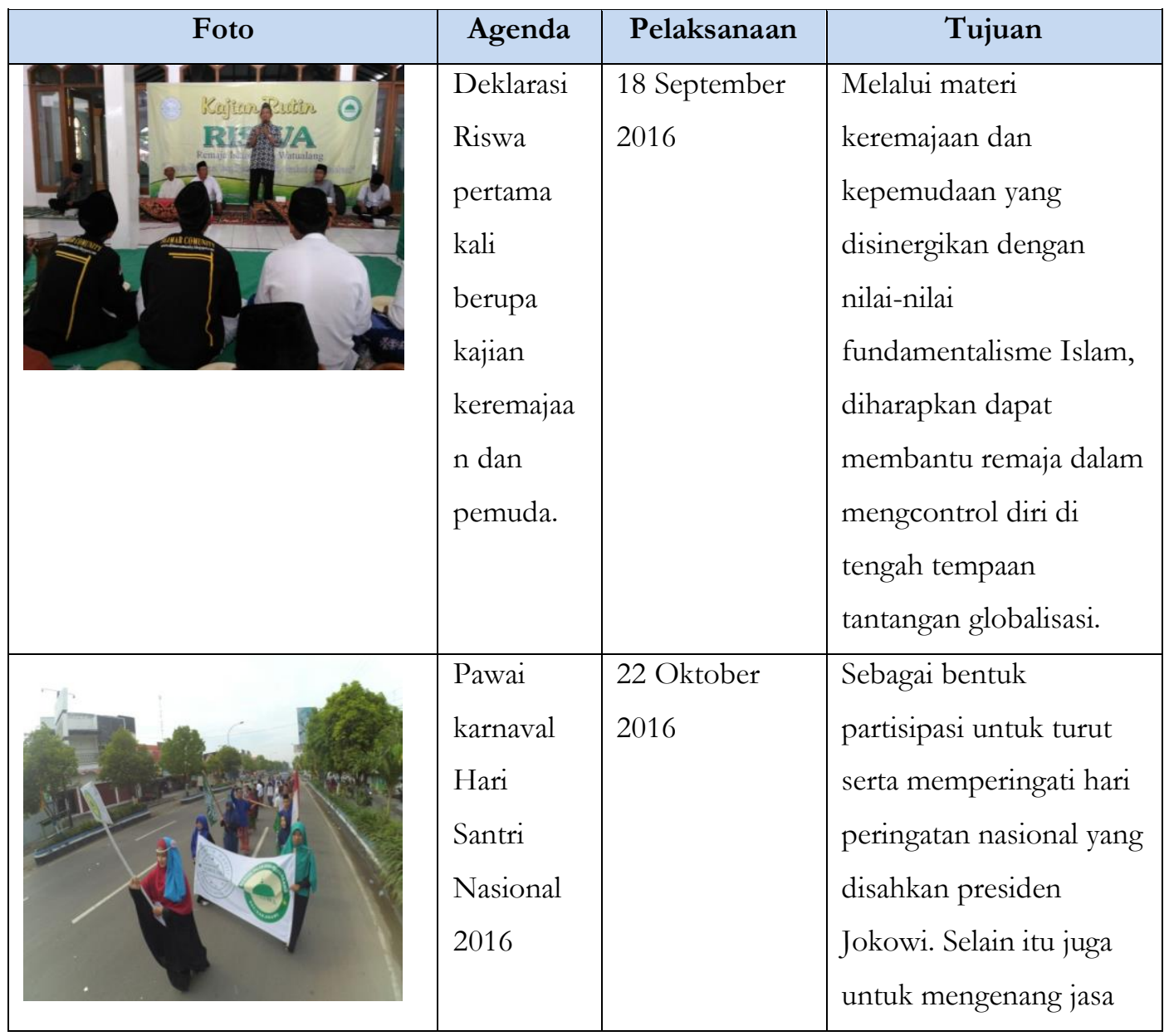




\begin{tabular}{|c|c|c|c|}
\hline & & & $\begin{array}{l}\text { para mujtahid ulama dan } \\
\text { santri dalam } \\
\text { kemerdekaan RI. }\end{array}$ \\
\hline 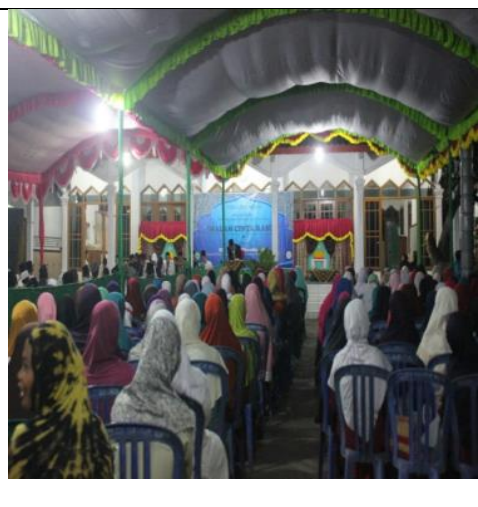 & $\begin{array}{l}\text { Pengajian } \\
\text { akbar } \\
\text { Maulid } \\
\text { Nabi } \\
\text { Muhamm } \\
\text { ad }\end{array}$ & $\begin{array}{l}26 \text { Desember } \\
2016\end{array}$ & $\begin{array}{l}\text { Selain untuk memediasi } \\
\text { pendidikan agama } \\
\text { kepada masyarakat, } \\
\text { pengajian ini sebagai } \\
\text { ajang mempererat } \\
\text { hubungan emosional } \\
\text { antara remaja dan } \\
\text { masyarakat umum. }\end{array}$ \\
\hline Wathe & $\begin{array}{l}\text { Seminar } \\
\text { Obras } \\
\text { (obrolan } \\
\text { remaja } \\
\text { cerdas) }\end{array}$ & $\begin{array}{l}\text { 09 Februari } \\
2017\end{array}$ & $\begin{array}{l}\text { Seminar dengan tema } \\
\text { "Hubbul Wathan Minal } \\
\text { Iman" ini memaparkan } \\
\text { tentang esensi pancasila } \\
\text { yang mengacu pada } \\
\text { piagam Madinah. } \\
\text { Melalui seminar ini, } \\
\text { diharapkan dapat } \\
\text { meningkatkan rasa } \\
\text { toleransi terhadap umat } \\
\text { manusia. }\end{array}$ \\
\hline 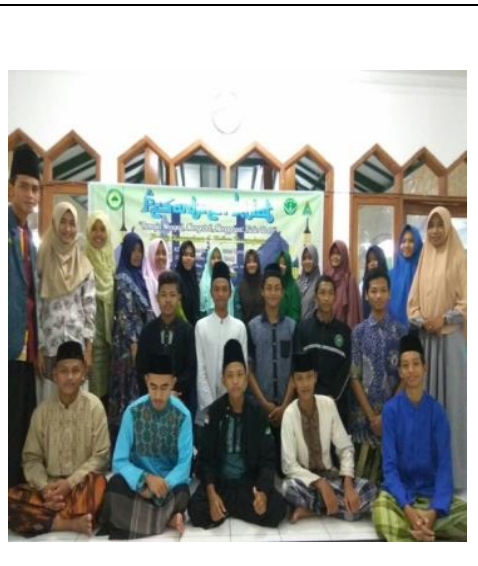 & $\begin{array}{l}\text { Pesantren } \\
\text { Kilat }\end{array}$ & $\begin{array}{l}04-06 \text { Juni } \\
2017\end{array}$ & $\begin{array}{l}\text { Pesantren kilat berisi } \\
\text { tentang penyampaian } \\
\text { materi sejarah Islam } \\
\text { beserta paham-paham } \\
\text { dari penganutnya } \\
\text { terdahulu. Materi ini } \\
\text { juga mencakup } \\
\text { pemaparan gerakan } \\
\text { transnasional dalam }\end{array}$ \\
\hline
\end{tabular}




\begin{tabular}{|c|c|c|c|}
\hline & & & $\begin{array}{l}\text { wujud radikalisme dan } \\
\text { terorisme. Melalui } \\
\text { materi ini, diharapkan } \\
\text { remaja dapat lebih } \\
\text { berhati-hati lagi } \\
\text { menerima doktrinasi isu } \\
\text { agama yang gencar } \\
\text { dengan radikalisme. }\end{array}$ \\
\hline$k^{2} 30$ & $\begin{array}{l}\text { Perwakila } \\
\text { n Pusat } \\
\text { Informasi } \\
\text { Konseling } \\
\text { Remaja } \\
\text { (PIK-R) } \\
\text { tingkat } \\
\text { kecamatan }\end{array}$ & 20 April 2017 & $\begin{array}{l}\text { Selain keagamaan, Riswa } \\
\text { menjadi mediator } \\
\text { konseling bagi remaja. } \\
\text { Melakukan penyuluhan } \\
\text { terkait bahaya Narkoba, } \\
\text { Seks Bebas, HIV Aids, } \\
\text { dan lainnya. }\end{array}$ \\
\hline $\cos$ & $\begin{array}{l}\text { Festival } \\
\text { Panggung } \\
\text { Merah } \\
\text { Memperin } \\
\text { gati HUT } \\
\text { RI }\end{array}$ & $\begin{array}{l}13-20 \text { Agustus } \\
2017\end{array}$ & $\begin{array}{l}\text { Meningkatkan } \\
\text { nasionalisme melalui } \\
\text { serangkaian acara, } \\
\text { seperti perlombaan, } \\
\text { seminar, dan perform } \\
\text { bakat group vokal koor, } \\
\text { hadrah, dan musik } \\
\text { perkusi. }\end{array}$ \\
\hline
\end{tabular}




\begin{tabular}{|c|c|c|c|}
\hline 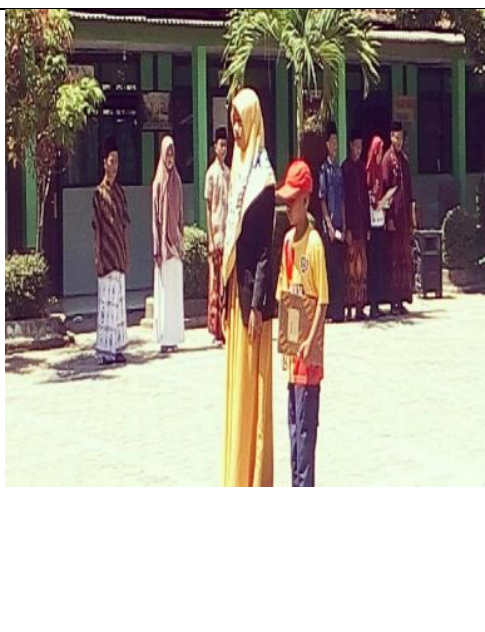 & $\begin{array}{l}\text { Prosesi } \\
\text { upacara } 17 \\
\text { Agustus } \\
\text { dengan } \\
\text { memakai } \\
\text { sarung }\end{array}$ & $\begin{array}{l}17 \text { Agustus } \\
2017\end{array}$ & $\begin{array}{l}\text { Sarung merupakan } \\
\text { warisan budaya bangsa. } \\
\text { Upacara peringatan } \\
\text { kemerdekaan } \\
\text { dilaksanakan khidmat } \\
\text { dengan amanat upacara } \\
\text { berupa penyampaian } \\
\text { urgensi mencintai tanah } \\
\text { air dan merawat } \\
\text { kebangsaan. }\end{array}$ \\
\hline 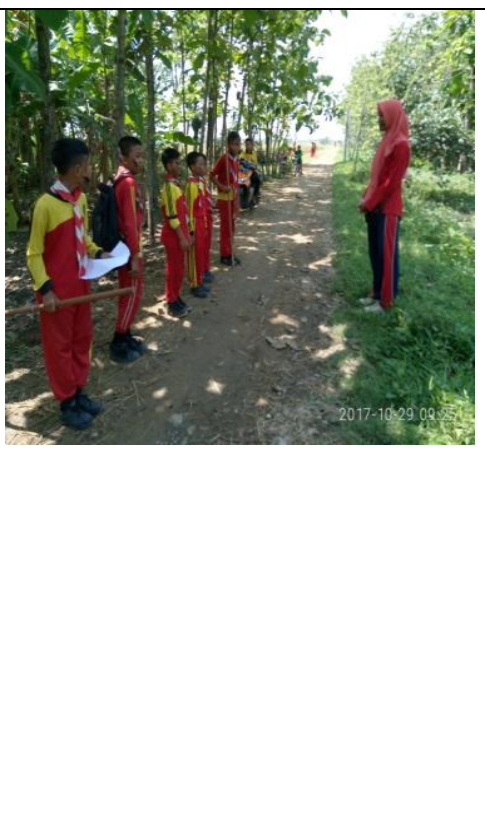 & $\begin{array}{l}\text { Outbond } \\
\text { Edukasi } \\
\text { memperin } \\
\text { gati Hari } \\
\text { Sumpah } \\
\text { Pemuda }\end{array}$ & $\begin{array}{l}29 \text { Oktober } \\
2017\end{array}$ & $\begin{array}{l}\text { Outbond edukasi diikuti } \\
\text { remaja dan anak-anak, } \\
\text { dengan konsep } \\
\text { menjelajah, peserta } \\
\text { diharapkan dapat akrab } \\
\text { dengan alam sebagai } \\
\text { bagian penting } \\
\text { kehidupan yang harus } \\
\text { dijaga. Outbond ini } \\
\text { ditutup dengan prosesi } \\
\text { upacara formal dengan } \\
\text { pembacaan teks Sumpah } \\
\text { Pemuda. }\end{array}$ \\
\hline
\end{tabular}




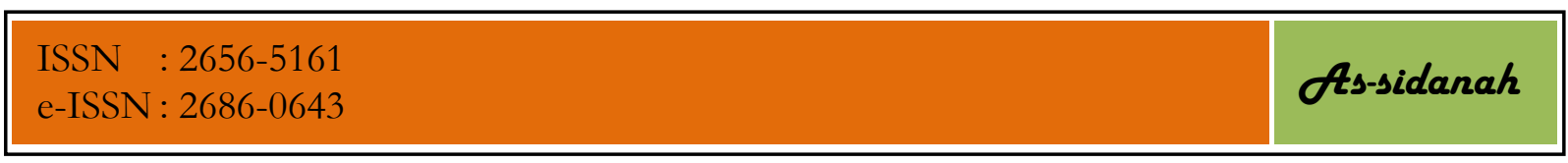

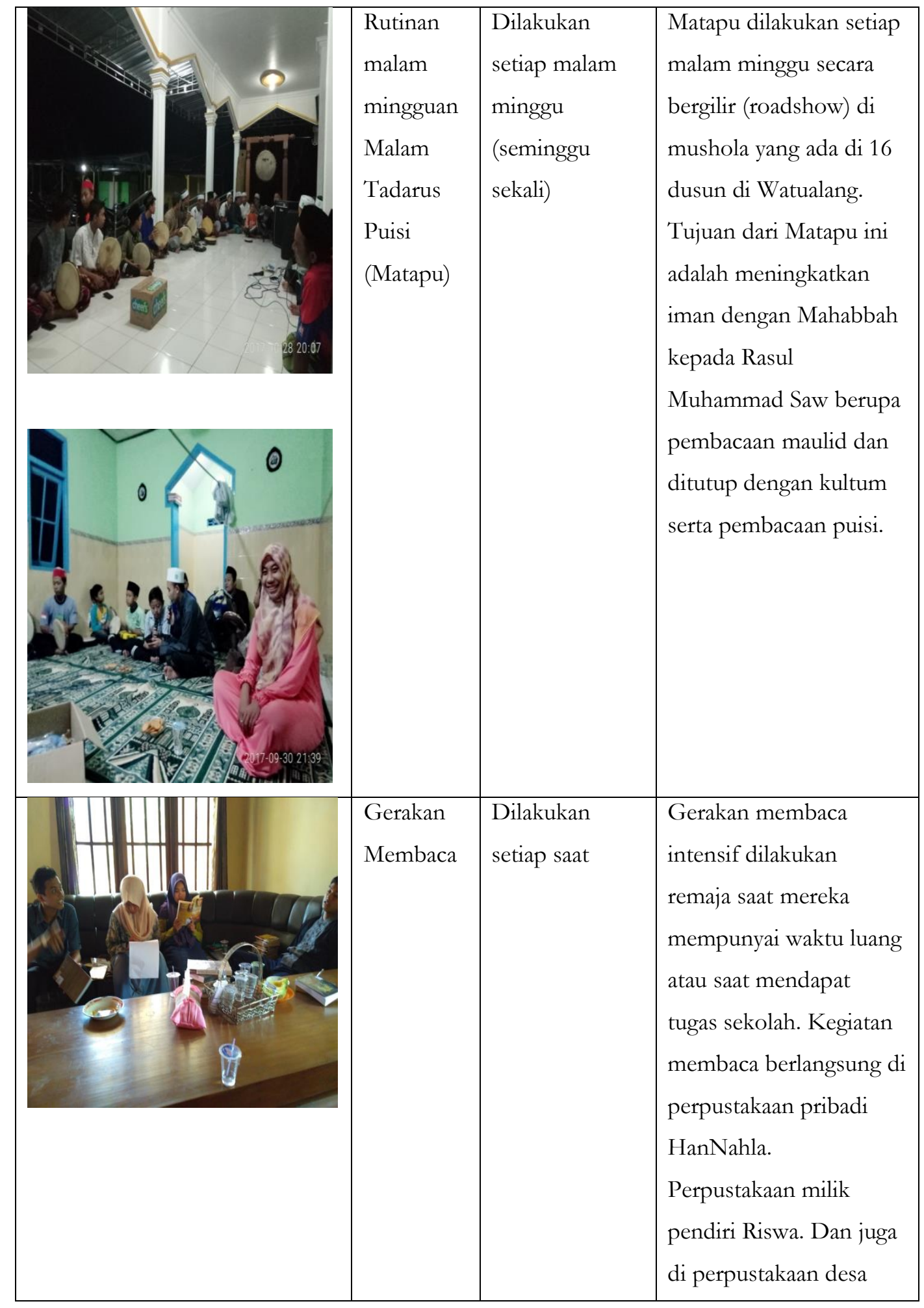

Vol. 1 No. 1, April 2019

Hanifah Hikmawati, S.S., M.Sos | Gurnal Pengabdian Masyarakat 


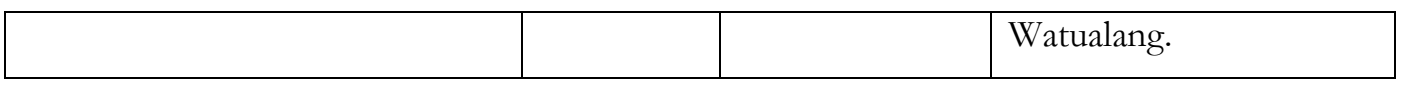

Gambar 2 : Tabel Kegiatan Riswa secara umum

\section{Harapan Dan Implementasi Nilai-Nilai Humanisme}

Berbagai kegiatan Riswa di atas menunjukkan bahwa terobosan dan kreativitas perlu diciptakan untuk menampung dahaga spiritualitas kaum muda. Tidak hanya cukup dari aspek modernitas, aspek inovatifitas juga perlu dimunculkan sebagai rangsangan progresifitas pemuda dalam meningkatkan kemajuan bangsa. Apalagi di era now, era di mana semua orang berhak menyuarakan pendapat. Terlepas dari ambisi subjektif untuk merealisasikan kepentingan tertentu, bagaimanapu juga perdamaian menjadi nomor satu untuk dijunjung.

Perdamaian memusatkan esensi kemanusiaan melalui toleransi pada era modernitas, sebagaimana yang dikatakan Clammer (2003:111), kekerabatan-kekerabatan tersebut akan menjadi penentu ketika hubungan antara basis dan superstruktur menjadikan basis sebagai superstrukturnya. Sehingga, segala bentuk kultus kehidupan dapat menjadi ladang subur untuk mengolah cita rasa. Sebagaimana pula yang diungkapkan Baghi (2014:120), mengatakan bahwa agama-agama terlepas dari segala keraguan dogmatis dan kognitifnya, menjadi tempat pengolahan simpati dan cita rasa yang paling kaya.

Tepat sekali jika kaum muda dan remaja perlu diberikan media pendidikan dan pembelajaran sebagai daya gedor membuka pintu kemanusiaan, mengingat manusia di era mutakhir kini banyak yang menciptakan dikotomi-dikotomi publik, konsep keagamaan Islam yang ramah, santun, tidak anarkis, menghormati segala pemeluk agama, kian menghilang dari jiwa manusia. Manusia terlampau mengagungkan apa yang dilihat secara kasat mata, tidak mau mengusut fakta kebenaran yang sebenarnya terjadi. Indonesia membutuhkan berbagai tradisi untuk melanggengkan konsep toleransi sebagai proses implementasi dziker dan ibadah yang mengandung sistem pendidikan. Syaikh Nazim (Netton, 2001:129) dan Jami (2003:xxxii) mengatakan bahwa driker itu penting demi kepuasan hidup ini, makna keikhlasan segala amalan dan achwal sumber kebijaksanaan dan kendaraan kuat dapat tersampaikan bagi jiwa untuk menuju kepada Allah Swt, sebagaimana Nabi Muhammad Saw menasihatkan bahwa segala sesuatu dapat diminta untuk orang-orang yang melaksanakan driker.

Untuk mencapai pemahaman tentang landasan 'normatif pada banyak pendekatan 
tradisional terhadap sosiologi pendidikan sepanjang karier, penting bagi kita untuk memperhatikan isu yang lebih luas dalam mengeksplisitkan asumsi-asumsi dan pendapatpendapat tentang nilai yang sudah menjadi sifat teori sosial secara lebih umum (Jenks, 2013:238). Dapat terlihat bagaimana berlangsungnya proses institusionalisasi dari suatu kultur, dari suatu bentuk kultural yang disebut sebagai sejarah melalui sistem pendidikan. Sistem ini didukung oleh kesadaran individu dalam kehidupan masyarakatnya, konsep dan ideologi atas legitimasi pendidikan yang terbentuk dari progresifitas kegiatan Riswa yang mengunggulkan rasa kemanusiaan itu dapat menjadi kesepakatan.

Hal ini didukung oleh perubahan orientasi ruang dalam masyarakat, yaitu satu tempat dengan tempat lain dengan mudah dihubungkan melalui pengalaman-pengalaman nyata yang dialami sendiri, termasuk nilai toleransi yang didapatkan dari Barzanjen sebagai adat dan salah satu terobosan dalam hukum syariat yang umum dipakai untuk menentukan corak hukum fiqih Islam nusantara mengacu pada kebiasaan, tradisi atau sesuatu yang diwariskan secara turuntemurun (Baso, 2015:131). Adat dan tradisi yang dilakukan Irswa dalam menjaga nilai nasionalisme melalui budaya mengalami perubahan karakter akibat interaksi dengan berbagai nilai yang terjadi di kelompok masyarakat. Sehingga, melalui interaksi tersebut, hegemonihegemoni Riswa dapat direpresentasikan oleh siapapun, sebagai sistem pendidikan yang dapat memberikan pengaruh bagi masing-masing individu, khususnya pada nilai toleransi dan kemanusiaan.

\section{Gerakan Ayo Membaca (Gam)}

Selain aktif dalam bidang keagamaan dan kebudayaan desa, Riswa juga aktif dalam bidang literasi berupa Gerakan Ayo Membaca (GAM) sudah 1 tahun ini dilaksanakan yang didukung dengan adanya revitalisasi Perpustakaan Desa Watualang. Proses revitalisasi ini mulai dilakukan Riswa pada bulan ramadhan 2018. Berliterasi adalah tantangan baru bagi kaum muda untuk berani melakukan perubahan. Spirit demikian ini menjadi modal awal dalam mengoptimalkan masa muda sebagai waktu dan momen yang tidak akan datang dua kali. Borgias (2013:53) mengatakan bahwa waktu selalu mengarah pada masa depan yang menjadi benang merah penghubung masa lalu yang kemudian membentuk tanda dinamika kehidupan manusia yang menyejarah. Maka, pemuda harus mempunyai cita-cita dalam menjemput masa 
depan sebagai masa keemasan yang tidak hanya berorientasi pada kelanggegan kehidupan keberagamaan, namun juga pada arah prospek literasi, pengetahuan dan pendidikan.
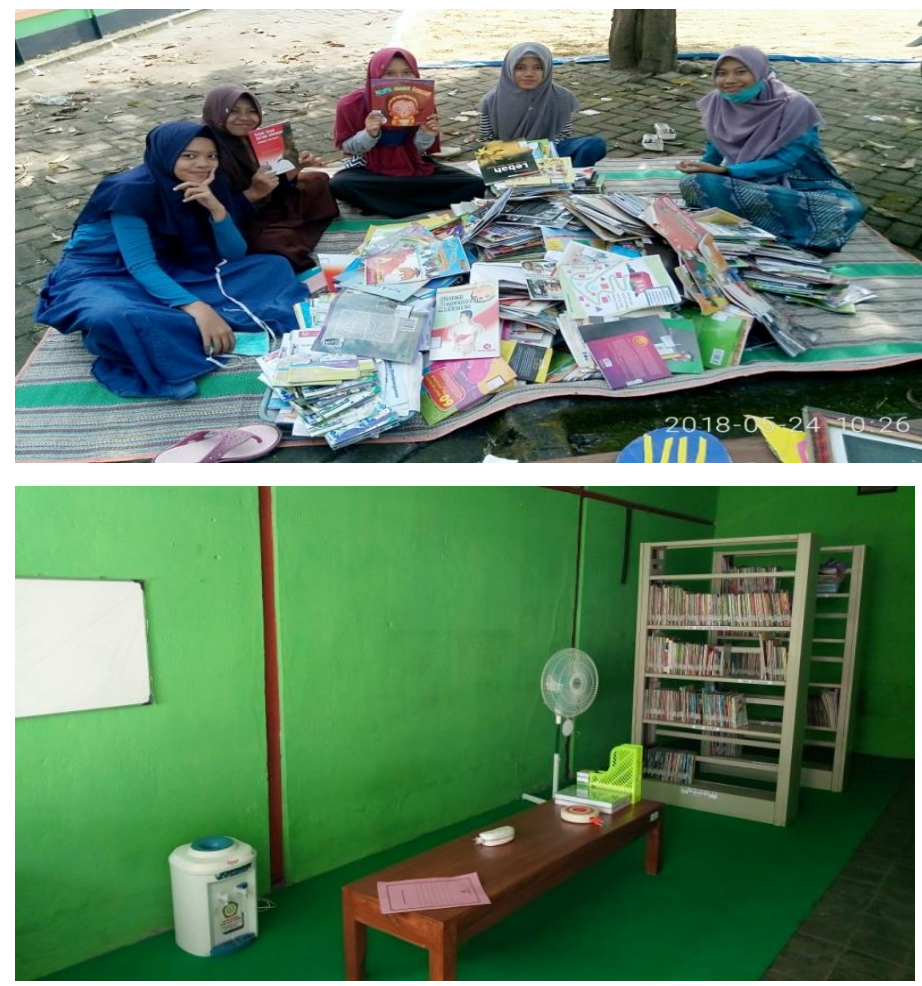

Perpustakaan menjadi peran media penting dalam pemerintahan yang terendah yaitu desa dan kelurahan. Hal ini berguna untuk menunjang kebutuhan intelektualitas dan pengetahuan masyarakat. Perpustakaan merupakan sarana penting dalam mencerdaskan generasi bangsa. Hal ini mengacu pada dikeluarkannya Keputusan Menteri Dalam Negeri dan Otonomi Daerah Nomor 3 Tahun 2001 tentang Perpustakaan Desa atau Kelurahan, perlu adanya perhatian yang khusus dalam upaya membangun dan mengembangkan Perpustakaan Desa atau Kelurahan. Agenda ini juga merupakan revitalisasi perpustakaan desa dalam menunjang gerakan literasi nasional sebagaimana yang dicanangkan pemerintah pada UndangUndang Nomor 20 Th 2003 tentang Sistem Pendidikan Nasional, Undang-undang Nomor 3 Tahun 2017 tentang sistem Perbukuan.

Dari pengertian tersebut terdapat empat kata kunci tentang perpustakaan desa yaitu: (1) perpustakaan berbasis masyarakat, (2) berfungsi sebagai sarana dan media belajar, (3) untuk

Vol. 1 No. 1, April 2019
Hanifah Hikmawati, S.S., M.Sos | gurnal Pengabdian Masyarakat 
meningkatkan dan mendukung pendidikan masyarakat, dan (4) merupakan bagian integral pembangunan. Jika dilihat dari empat kata kunci tersebut pengertian hakiki dari perpustakaan desa adalah perpustakaan yang dikembangkan dan didirikan atas inisitif dan prakarsa dari pemerintah desa, penyelenggaraannya juga menjadi tanggung jawab pemerintah desa, yang digunakan masyarakat sebagai media untuk mendukung pendidikan informal di lingkungan masyarakat yang menjadi bagian yang tak terpisahkan dari program pembangunan dalam pelaksanaan pembangunan desa.

\section{Penutup}

Pengabdian terhadap Riswa menjadi sebuah terobosan baru dalam memberdayakan sumber daya manusia di desa, yaitu kaum remaja/pemuda. Hal ini dikarenakan kebutuhan remaja era sekarang membutuhkan kreativitas corak dakwah yang tidak membosankan. Pertama, ancaman radikalisme dan terorisme sudah menjadi ancaman bersama sekaligus menjadi kewajiban bersama seluruh masyarakat Indonesia untuk melindungi diri dan mampu menciptakan wadah untuk menanggulanginya. Keresahan yang menjadi ketakutan bersama juga wajib untuk diperangi melalui ajaran positif dan mendidik. Kedua, berbagai kegiatan yang dilaksanakan Riswa mampu membuat remaja mendapat wawasan dan dinamika baru terkait esensi keislaman yang moderat dan humanis. Hal ini penting disadari bersama agar kaum pemuda/remaja tidak terjerumus pada bahaya-bahaya yang mengancam.

\section{DAFTAR PUSTAKA}

Arifin, Syamsul. 2014. Membendung Arus Radikalisasi di Indonesia. Jurnal Islamica: Jurnal Studi Keislaman, Vol.8, No.2, ISSN: 1978-3183; 392-420.

Baghi, Felix. 2014. Redeskripsi dan Ironi - Mengolah Cita Rasa Kemanusiaan. Nusa Tenggara Timur: Ledalero.

Baso, Ahmad. 2015. Islam Nusantara. Jakarta: Pustaka Afid.

Borgias M, Fransiskus. 2013. Manusia Pengembara - Refleksi Filosofis tentang Manusia. Yogyakarta: Jalasutra.

Clammer, John. 2003. Neo-Marxisme Antropologi: Studi Ekonomi Politik dan Pembangunan.

Diterjemahkan oleh Ilham B. Saenog. Yogyakarta: Sadasiva.

Fanani, Ahmad Fuad. Fenomena Radikalisme di Kalangan Kaum Muda. 2013. Jurnal Maarif - Arus 
Pemikiran Islam dan Sosial. Menghalau Radikalisasi Kaum Muda: Gagasan dan Aksi. Maarif Institute for Culture and Humanity Jakarta. ISSN: 1907-8161.

Hikmawati, Hanifah \& Pitana, Titis Srimuda. 2008. Taubid dari Rimba Watualang - Oneness of God's Concept from Rimba Watualang. Jurnal Ibda' - Jurnal Kajian Islam dan Budaya IAIN Purwokerto, Vol.16, No.1, Mei 2018, ISSN: 1693-6736.

http://www.nu.or.id/post/read/90645/radikalisme-yang-menyebar-secara-senyap-padaremaja-dan-pemuda. diakses pada 28 Januari 2019 pkl. 10:16 wib.

Jami, Mawlana Abu ar-Rahman. Nafahat al-Uns min Hadarat al-Quds. diterjemahkan oleh Broer R. Soenardi. 2003. Pancaran Ilahi Kaum Sufi. Yogyakarta: Penerbit Pustaka Sufi.

Jenks, Chris. 2013. Culture. diterjemahkan oleh Erika Setyawati. Studi Kebudayaan. Yogyakarta: Pustaka Pelajar.

Netton, Ian Richard. 2001. Dunia Spiritual Kaum Sufi. diterjemahkan oleh Machnun Husein. Jakarta: Raja Grafindo Persada.

Qodir, Zuly. 2007. Islam Syariah vis a vis Negara - Ideologi Gerakan Politil di Indonesia. Yogyakarta: Pustaka Pelajar.

Winarni, Leni. Dalam Prosiding Internasional. 2016. International Conference on Middle East and Sonet East Asia (IcoMS) 26-27 Oktober 2016 - Actualizing the Values of Humanism to Avoid the Global Terrorism. Sebelas Maret University. 